$2019,20(1)$, pp. 92 - 103, DOI: 10.18038/aubtda.439123

\title{
INVESTIGATION OF MACHINABILITY OF WELDED JOINTED HARDOX STEEL IN WEDM
}

\author{
Mehmet ALTUĞ * \\ Department of Machine and Metal Tech., Malatya Vocational High School, Inonu University, Malatya, Turkey
}

\begin{abstract}
In this study machinibility of hardox steel plates (welded by plasma and Mag welding) was examined in WEDM. Two different ampere values and two different feed rates were determined for the two different welding types. Depending on these factors ,micro structures, micro hardnesses and resistivity/conductivity values (varying according to heat output) were obtained at the HAZ and WM zones. Then, each of the samples taken from both HAZ and WM zones were cut in the WEDM by using 2 levelled four different parameters. The purpose at this stage is to examine the cutting width (kerf) and surface roughness $(\mathrm{Ra})$ values at the HAZ and WM zones with respect to varying micro structure, micro hardness and conductivity values. At the end of the study, the lowest kerf was obtained with the plasma welded samples whereas the lowest Ra values were obtained with the Mag welded samples. The samples at WM zone are in general are the ones welded by high conductivity sample Mag welding. Whereas in the HAZ zone the samples are the ones welded by high conductivity plasma welding.
\end{abstract}

Keywords: Hardox steel, Plasma welding, MAG welding, WEDM, Kerf, Ra

\section{INTRODUCTION}

Wire electrical discharge machining (WEDM) is basically a non conventional material removal process used in numerous applications as tool, mold, automotive, aerospace and medical industries to produce complex shapes. The WEDM can be successfully employed to the electrically conductive components irrespective of their hardness, microstructure, shape, and toughness [1-3]. This process has some machining outcomes such as material removal rate (MRR), kerf, and surface roughness [47]. These machining outcomes depend on machining parameters such as ignition pulse current, timebetween two pulses, servo reference voltage,wire speed, wire tension, and injection pressure [812]. It is known that the WEDM parameters play a significant role in minimization of the cutting width and surface roughness. While there are much studies with the weldability and heat treatment of hardox steels (13-15), there are very few studies on machinability. Some of these studies are related to waterjet (16) and laser plasma and plasma cutting (17-21).

Hardox steels high wear resistance provides intensive use in the industry. In this study, the machinability of hardox gripper, which is used for the transportation of bolts and nuts products to different stations, has been investigated. In this study, Hardox sheets were joined via different welding metot, amper and feed rate. The effect of these parameters were investigated on the weld metal (WM), width of the HAZ, microstructure, microhardness, conductivity and machinability in WEDM. The studies in literature about Plasma and MAG joining Hardox sheets are few in number. Besides, detailed literature review has showed that a number of studies examining kerf characteristics of work piece based on Hardox steels joined with plasma and MAG weld are limited and the studies published in a limited number have not been comprehensive. This study will contribute to filling this information gap. The machinability of welded samples was carried out by the WEDM. The kerf values of welded samples were measured perpendicular to the welded zones such as the WM and the HAZ.

*Corresponding Author: mehmet.altug@inonu.edu.tr

Received: 29.06.2018 Accepted: 19.03.2019 
For this reason, this study investigated effects of microhardness, microstructure and conductivity of the sample with WEDM parameters- current, time off, wire speed and wire tension- and revealed effect of interaction of feature-parameter with kerf and Ra.
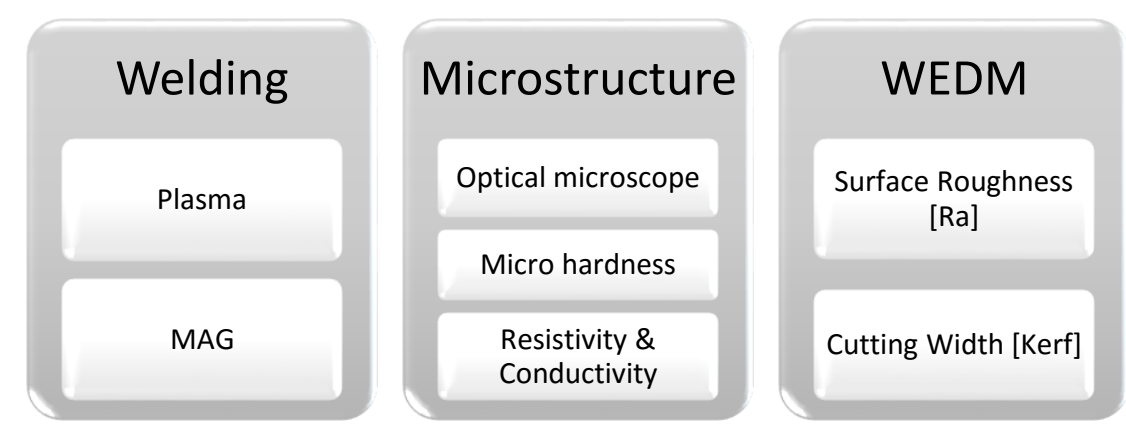

Figure 1. The flowchart of the processes in this study

\section{MATERIALS AND METHOD}

Microstructures, microhardness, and electric conductivity of samples of Hardox Steel welding jointed different welding were examined in this study. The sizes of kerf and Ra were measured with Taguchi experimental design by cutting them in the wire bench as specified by the experimental study. The ANOVA and 3D graphics were examined by using Minitab 14 program. Welding specified in Table 1 were applied to Hardox Steel, chemical compound of which is present in Table 2, mechanical properties of which is present in Table 3 under normal atmosphere conditions. These samples welded jointed were processed with WEDM by using the parameters in Table 4. In order to determine the sample features, which were changing as a result of welded jointed; microhardness, optical microscope in Nikon device, microstructure, mechanical features and conductivity to machinability with WEDM were investigated.

Table 1. Welding process and parameters

\begin{tabular}{|cccc|}
\hline Sample & Welding & Ampe & Feed \\
\hline 1 & Plasma & 180 & 0,1 \\
\hline 2 & Plasma & 200 & 0,15 \\
\hline 3 & MAG & 180 & 0,1 \\
\hline 4 & MAG & 200 & 0,15 \\
\hline
\end{tabular}

Table 2. Chemical composition of Hardox Steel

\begin{tabular}{|cccccccccc|}
\hline Element & $\mathbf{C}$ & $\mathbf{S i}$ & $\mathbf{M n}$ & $\mathbf{P}$ & $\mathbf{S}$ & $\mathbf{C r}$ & $\mathbf{N i}$ & $\mathbf{M o}$ & $\mathbf{B}$ \\
\hline [wt. \%] & 0,32 & 0,70 & 1,60 & 0,025 & 0,010 & 2,50 & 1,50 & 0,60 & 0,004 \\
\hline
\end{tabular}

Table 3. Mechanical properties of Hardox Steel

\begin{tabular}{|ccccc|}
\hline Tensile strength & Yield strength & Impact energy & Hardness & Elongation \\
\hline $\mathbf{1 0 8 0}$ & $900-1100$ & 45 & $370-430$ & 8 \\
\hline
\end{tabular}

Experimental trials were carried out in a AF 250 high precision CNC WEDM. The experimental setup was as follows: Zinc coated brass wire with $0.25 \mathrm{~mm}$ diameter was employed as an electrode, and dimensions of Hardox steel samples were $5 \mathrm{~mm}$ x $50 \mathrm{~mm}$ x $100 \mathrm{~mm}$ in all the experiments. The behavior of four control factors as welding jointed samples, time off, wire speed, wire tension and dielectric was examined in this study. Table 4 illustrates control factors and their levels with codes. The kerf value was measured by using LEICA DM4000M optical microscope device. The Ra value was measured by using Taylor Hobson device. The experimental observations were further converted into a signal-to- 
noise $(\mathrm{S} / \mathrm{N})$ ratio by using Eq. (1) The signal-to-noise $(\mathrm{S} / \mathrm{N})$ ratio for "Smaller is better" was calculated as follows [22];

Smaller is better;

$$
S / N_{S}=-10 \log \left(\frac{1}{n} \sum_{i=1}^{n} y_{i}^{2}\right)
$$

Table 4. Parameters and Levels

\begin{tabular}{|clcccc|}
\hline Code & \multicolumn{1}{c}{ Parameters } & \multicolumn{4}{c|}{ Levels } \\
\hline $\mathbf{H}$ & $\begin{array}{l}\text { Hardox welded } \\
\text { jointed Samples }\end{array}$ & $\mathbf{1}$ & $\mathbf{2}$ & $\mathbf{3}$ & $\mathbf{4}$ \\
\hline $\mathbf{T}_{\mathbf{f f r}}$ & Time off $(\mu \mathrm{s})$ & $\mathbf{2 0 0}$ & $\mathbf{4 0 0}$ & & \\
\hline $\mathbf{W}_{\mathbf{s}}$ & Wire speed $(\mathrm{m} / \mathrm{min})$ & $\mathbf{4}$ & $\mathbf{8}$ & & \\
\hline $\mathbf{W}_{\mathbf{t}}$ & Wire Tension $(\mathrm{g})$ & $\mathbf{1 2}$ & $\mathbf{1 8}$ & & \\
\hline $\mathbf{D}_{\mathbf{e}}$ & Dielectric $($ bar $)$ & $\mathbf{4}$ & $\mathbf{8}$ & & \\
\hline
\end{tabular}

\section{RESULT AND DISCUSSION}

\subsection{Microstructure and Effect of Weld Parameters}

In this study, commercial item microstructure having no heat treatment has tempered martensite phase structure (Figure 2). These steels are produced fully hardened and supplied to the industry [13, 15].

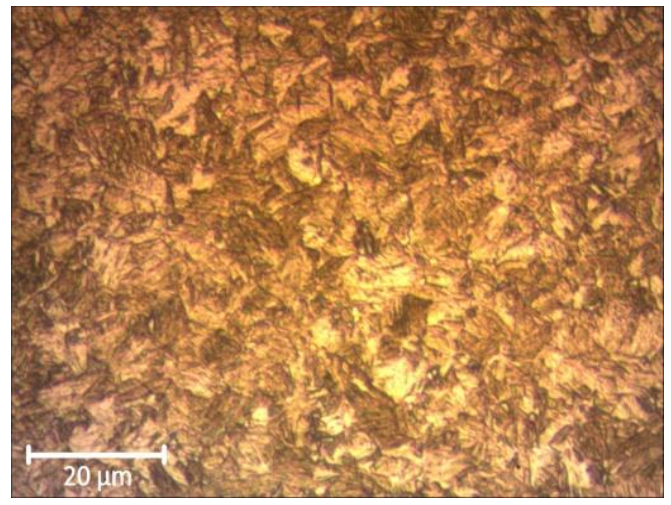

Figure 2. The optical microscope images of the Hardox 400

In Figure 3(a), the micro structure of heat affected zone (HAZ) welded by MAG welding method using 200 ampere is given. Welding heat caused a tempering effect in this zone and consequently micro structure has changed. Especially, occurrence of small sized $\alpha$-ferrit phase was detected at the grain boundaries of the zone near the weld metal. In Figure 3 (b), the weld metal (WM) microstructure of the sample welded by MAG welding method using 200 ampere. Weld metal microstructure was in the form of a complex structure. $\alpha$-ferrite phase morphology was observed to be generally dendritic and it was from time to time spherical. Among the dendtric phases nonhomogeneous pearlite phase was observed. In Figure 4 (a), HAZ microstructure of the sample welded by MAG method using 180 ampere is given. Welding heat created a tempering effect in this zone and microstructure changed but since there is a decrease in the heat input due to lower amperage, this change is not as much as the one in the Figure 3 (a). In Figure 4(b), weld metal micro structure of the sample welded by MAG method using 180 ampere is given. In the weld metal microstructure $\alpha$-ferrite phase morphology is dendritic. Among the dendritic phases a thin pearlite phase was observed. It was specified that in Figure 4(b) a thinner dendritic ferrite phase was obtained compared to the weld metal morphology in Figure 3(b). It is thought that the main reason of this situation is the decrease in the heat input. 


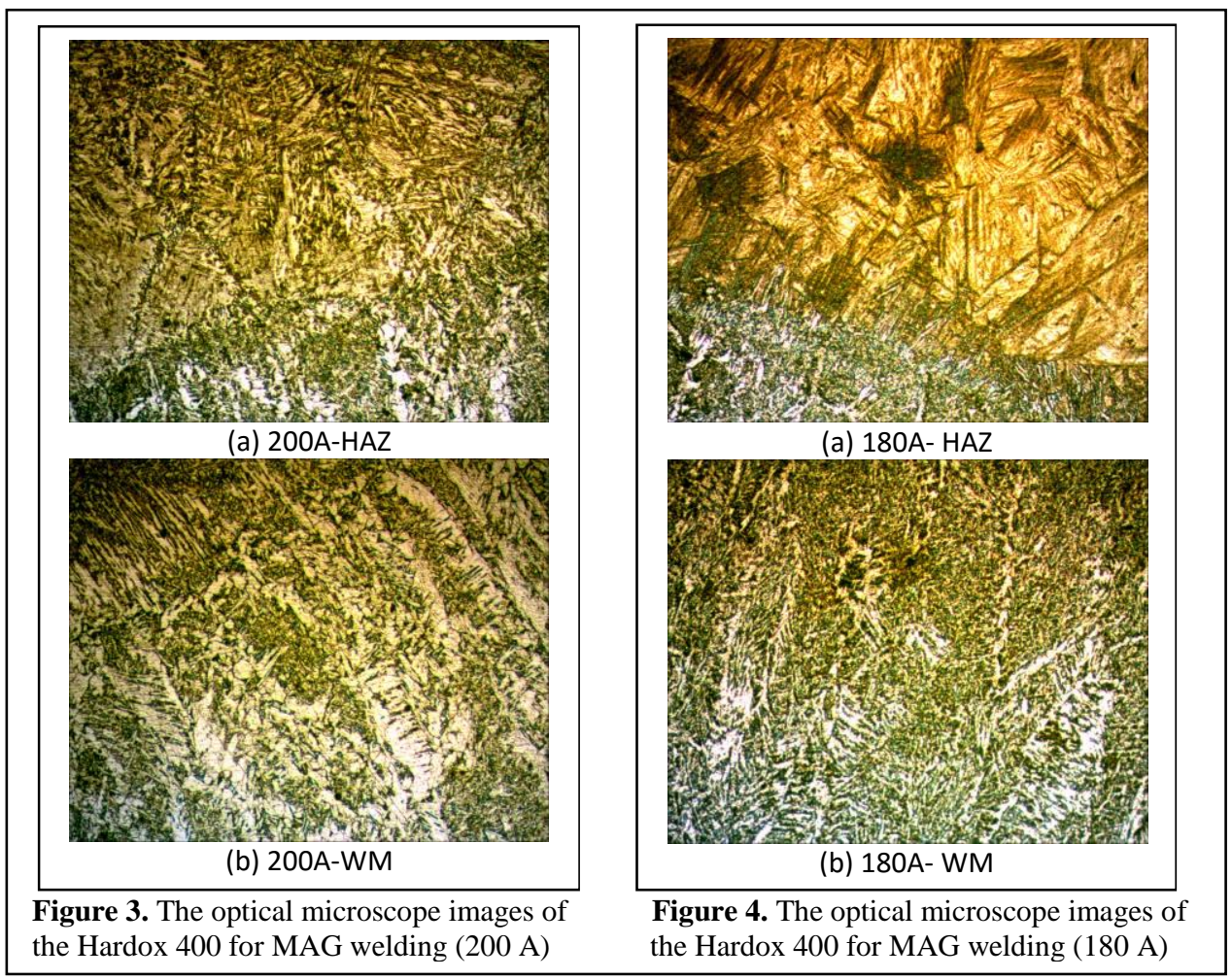

HAZ microstructures of the samples welded by plasma method using 200 and 180 ampere were given in Figure 5(a) and Figure 6(a) respectively.Microstructures in HAZ changed depending on the tempering effect caused by the welding heat. In Figure $5 \mathrm{~b}$ and Figure c, weld metal microstructure of the samples welded by plasma welding method using 200 and 180 ampere is given.

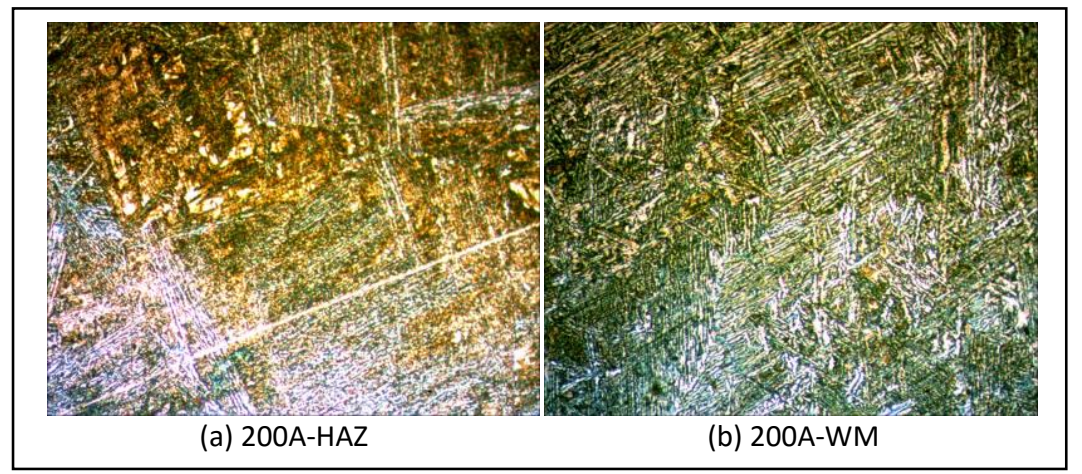

Figure 5. The optical microscope images of the Hardox 400 for Plasma welding (200 A)

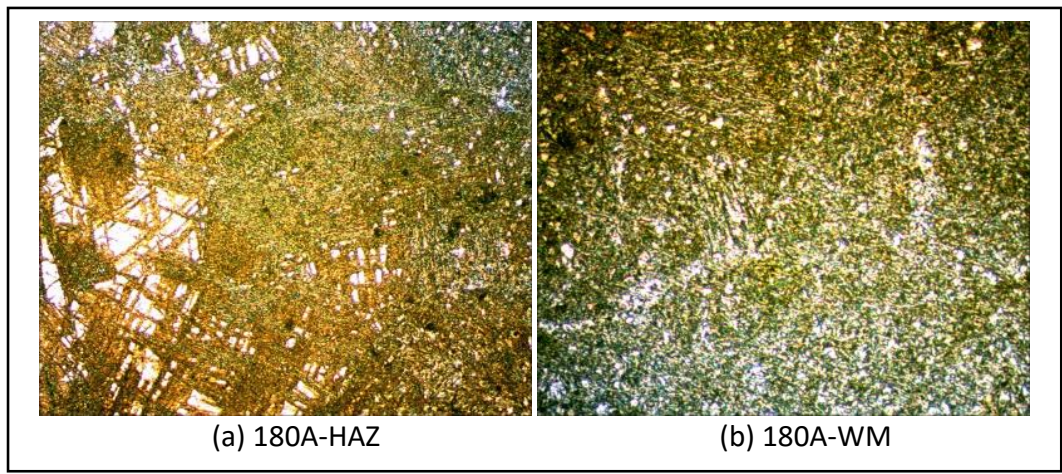

Figure 6. The optical microscope images of the Hardox 400 for Plasma welding (180 A) 
Effect of heat input and cooling rate on the morphology of these microstructures bir was explicitly seen. It was specified that while lamellar bainite was dominant in the weld metal micro structure of the sample (Figure 5-b) having high heat input , in the weld metal microstructure of the sample (Figure 6b) with lower heat input, a nonlamellar finely distributed bainite was dominant.

\subsection{Microhardness}

In Table 1 hardness values (graphic) of the samples joined by different welding method and parameters are given. ITAB and WM (weld metal) hardness values of the sample welded by MAG method using 200 ampere came out to be low compared to ITAB and WM hardness values of the sample welded by MAG method using 180 ampere. The main reason of this is the heat input and cooling rate. As the heat input increases cooling rate slows down and hardness decreases accordingly. Similar case is valid for the plasma welding. In other words lower heat input caused the increase of hardness. These results are in consistency with the results in literature [13].

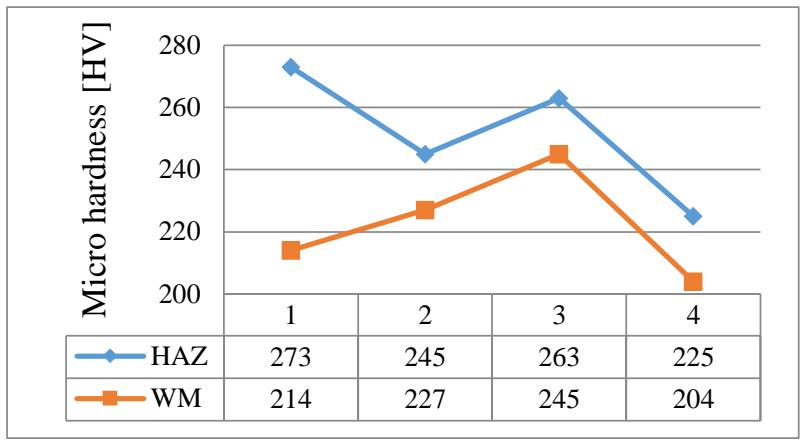

Figure 7. Micro hardness results of the welded samples

\subsection{Resistivity and Conductivity}

Different microstructures of the welded samples in ITAB affected the electrical conductivity too. While conductivities of these microstructures exhibits discrepancy, the resistivities dropped with the increasing temperature. The resistivity of the sample with a higher hardness value at room temperature came out to be high whereas the resistivity of the samples with lower hardness value was low. Similar case is valid for the weld metal. Namely. resistivities at room temperature exhibited change due to different micro structure and hardness. Resistivities showed similarity with the increasing temperature.

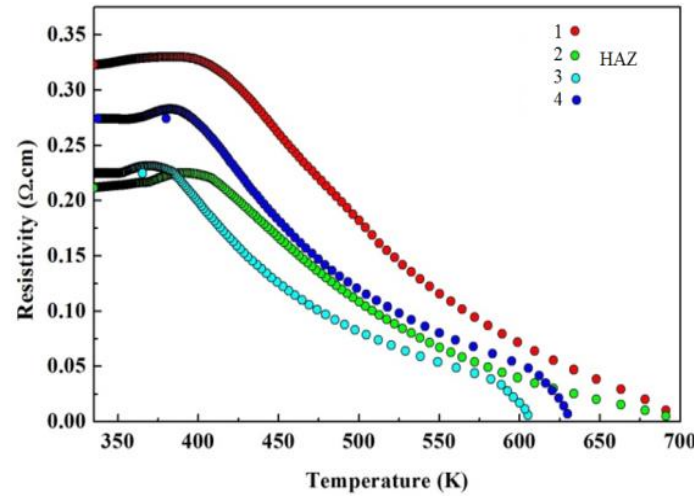

(a)

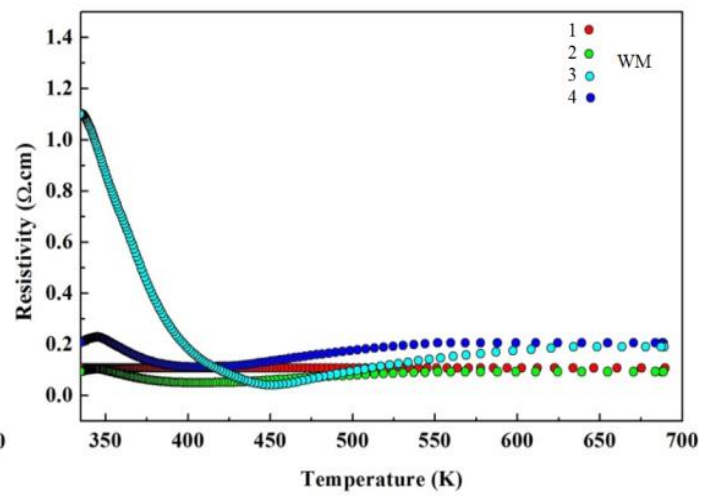

(b)

Figure 8. The resistivity results of the welded samples a) Heat affected zone b) Welding metal

\subsection{Kerf (Cutting Width)}

The kerf and surface roughness ( $\mathrm{Ra}$ ) values obtained as a result of the experiments on the WEDM are given in Table 5. 
Table 5. Taguchi $\mathrm{L}_{16}$ orthogonal array and experimental results

\begin{tabular}{|c|c|c|c|c|c|c|c|c|c|}
\hline \multirow{3}{*}{$\begin{array}{c}\text { Exp } \\
\text { No }\end{array}$} & \multirow{2}{*}{\multicolumn{5}{|c|}{ Parameters }} & \multicolumn{4}{|c|}{ Results } \\
\hline & & & & & & \multicolumn{2}{|c|}{ Kerf } & \multicolumn{2}{|c|}{$\mathrm{Ra}$} \\
\hline & Hardox & $\mathrm{T}_{\text {off }}$ & $\mathrm{W}_{\mathrm{s}}$ & $\mathrm{W}_{\mathrm{t}}$ & $D_{e}$ & HAZ & WM & HAZ & WM \\
\hline 1 & 1 & 200 & 4 & 12 & 4 & 245 & 225 & 3,42 & 3,64 \\
\hline 2 & 1 & 200 & 4 & 12 & 4 & 248 & 227 & 3,46 & 3,65 \\
\hline 3 & 1 & 400 & 8 & 18 & 8 & 253 & 226 & 3,43 & 3,62 \\
\hline 4 & 1 & 400 & 8 & 18 & 8 & 254 & 225 & 3,46 & 3,62 \\
\hline 5 & 2 & 200 & 4 & 18 & 8 & 253 & 220 & 3,37 & 3,64 \\
\hline 6 & 2 & 200 & 4 & 18 & 8 & 255 & 222 & 3,39 & 3,69 \\
\hline 7 & 2 & 400 & 8 & 12 & 4 & 255 & 227 & 3,40 & 3,65 \\
\hline 8 & 2 & 400 & 8 & 12 & 4 & 256 & 228 & 3,41 & 3,69 \\
\hline 9 & 3 & 200 & 8 & 12 & 8 & 251 & 227 & 3,40 & 3,53 \\
\hline 10 & 3 & 200 & 8 & 12 & 8 & 253 & 229 & 3,43 & 3,57 \\
\hline 11 & 3 & 400 & 4 & 18 & 4 & 252 & 229 & 3,41 & 3,64 \\
\hline 12 & 3 & 400 & 4 & 18 & 4 & 251 & 230 & 3,40 & 3,67 \\
\hline 13 & 4 & 200 & 8 & 18 & 4 & 250 & 224 & 3,31 & 3,59 \\
\hline 14 & 4 & 200 & 8 & 18 & 4 & 250 & 224 & 3,35 & 3,61 \\
\hline 15 & 4 & 400 & 4 & 12 & 8 & 251 & 225 & 3,42 & 3,62 \\
\hline 16 & 4 & 400 & 4 & 12 & 8 & 252 & 226 & 3,44 & 3,63 \\
\hline
\end{tabular}

\subsubsection{Heat affected zone}

Kerf values consisted on the HAZ are given in Figure $7 \mathrm{~b}$. From the figure it is seen that the lowest Kerf value was obtained with the 1,4,3,2 samples respectively. According to these results the lowest kerf in the HAZ was obtained with plasma welding, 180 ampere and with $0,1 \mathrm{~mm} / \mathrm{min}$ feed. Here the kerf results can be attributed to the changes in hardness. Besides, an increase was also observed in kerf values with the increasing of all of the WEDM parameter values. The results show similarity with some studies in literature $[1,5,12]$. The main reason of the differences between kerf values of samples is the microstructure, micro hardness and conductivity values changing depending on the heat inputs of welding parameters.

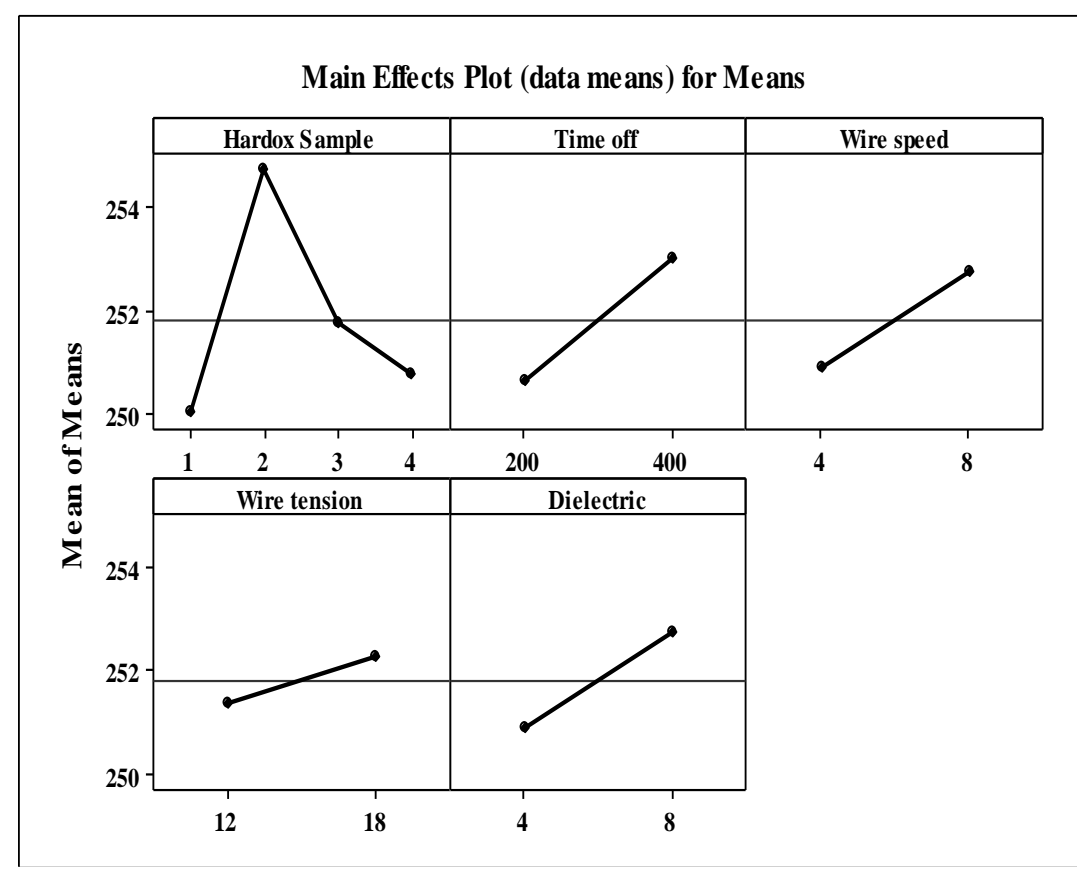

Figure 9. Effects of parameters on kerf (HAZ) 
In Table.6 the ANOVA analysis with which the effects of welding method and WEDM parameters on kerf in the HAZ is examined. According to the Table it was observed that different welding method and WEDM parameters such as time off , wire feed and dielectric were significantly effective on kerf. The difference in the kerf values of hardox samples welded by different welding methods and welding parameters shows the accuracy and contributions of the application.

Table 6. Result of ANOVA for Kerf of HAZ

\begin{tabular}{|lccccc|}
\hline Source & DF & SS & MS & F & P \\
\hline Hardox & 3 & 52,188 & 17,396 & 13,25 & 0,002 \\
\hline Time off & 1 & 22,563 & 22,562 & 17,19 & 0,003 \\
\hline Wire feed & 1 & 14,062 & 14,062 & 10,71 & 0,011 \\
\hline Wire Tension & 1 & 3,062 & 3,062 & 2,33 & 0,165 \\
\hline Dielectric & 1 & 14,063 & 14,063 & 10,71 & 0,011 \\
\hline Residual Error & 8 & 10,500 & 1,313 & & \\
\hline Total & 15 & 116,438 & & & \\
\hline
\end{tabular}

\subsubsection{Welding metal}

Kerf values in the WM zone are given in Figure 8. According to the Figure, the lowest kerf value was obtained in the samples 2, 4, 1 and 3 respectively. According to these results the lowest kerf in the WM zone was obtained at plasma welding, 200 ampere and $0,15 \mathrm{~mm} / \mathrm{min}$ feed. Another lower kerf value was obtained with sample no. 4 again at 200 ampere. Besides, in the WM zone, an increase in the kerf values was also observed with increasing WEDM parameters such as time off and wire speed. But a general drop was seen in kerf values in case of an increase in wire tension and dielectric values. Similar results shows analogy with some studies in literature $[1,5,12]$.

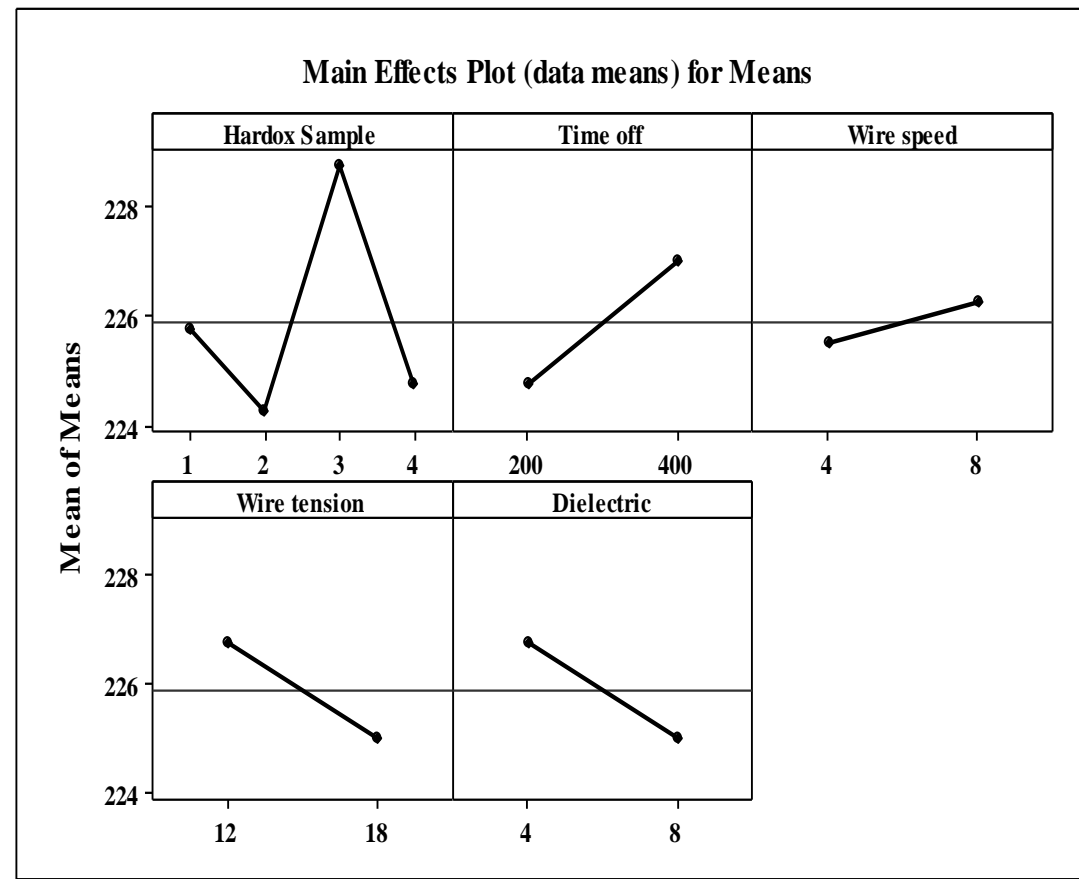

Figure 10. Effects of parameters on kerf (WM)

In Table.7 ANOVA analysis with which the effects of welding method and WEDM parameters on kerf in the WM zone is examined is given. According to the Table, different welding method and WEDM parameters such as time off, wire tension and dielectric was significantly effective on kerf .The difference in the kerf values of Hardox samples welded by different welding methods and welding parameters shows the accuracy and contributions of the application. 
Table 7. Result of ANOVA for Kerf of WM

\begin{tabular}{|lccccc|} 
Source & DF & SS & MS & F & P \\
\hline Hardox & 3 & 48,750 & 16,250 & 16,25 & 0,001 \\
\hline Time off & 1 & 20,250 & 20,250 & 20,25 & 0,002 \\
\hline Wire feed & 1 & 2,250 & 2,250 & 2,25 & 0,172 \\
\hline Wire Tension & 1 & 12,250 & 12,250 & 12,25 & 0,008 \\
\hline Dielectric & 1 & 12,250 & 12,250 & 12,25 & 0,008 \\
\hline Residual Error & 8 & 8,000 & 1,000 & & \\
\hline Total & 15 & 103,750 & & & \\
\hline
\end{tabular}

\subsection{Surface Roughness (Ra)}

\subsubsection{Heat affected zone}

Ra values of HAZ are given in Figure 9. According to the Figure, the lowest Ra value was obtained with the samples $4,2,3$ and 1 . According to these results the lowest Ra value in the HAZ was obtained at the same ampere $(200 \mathrm{~A})$ and same feed $(0,15 \mathrm{~mm} / \mathrm{min})$ (even in different welding methods). Again according to these results the lowest Ra values in the HAZ was obtained with the samples having the lowest conductivity. Besides, with the increasing WEDM parameters such as time off and dielectric, there is a general increase in the Ra values too. On the other hand, a general drop was observed in Ra values with the increasing wire speed and wire tension values. Similar results shows analogy with some studies in literature [5, 11, 23]. The main reason of the discrepancies between Ra values of the samples in HAZ are the microstructure,micro hardness and conductivity values changing depending on the heat inputs of welding parameters.

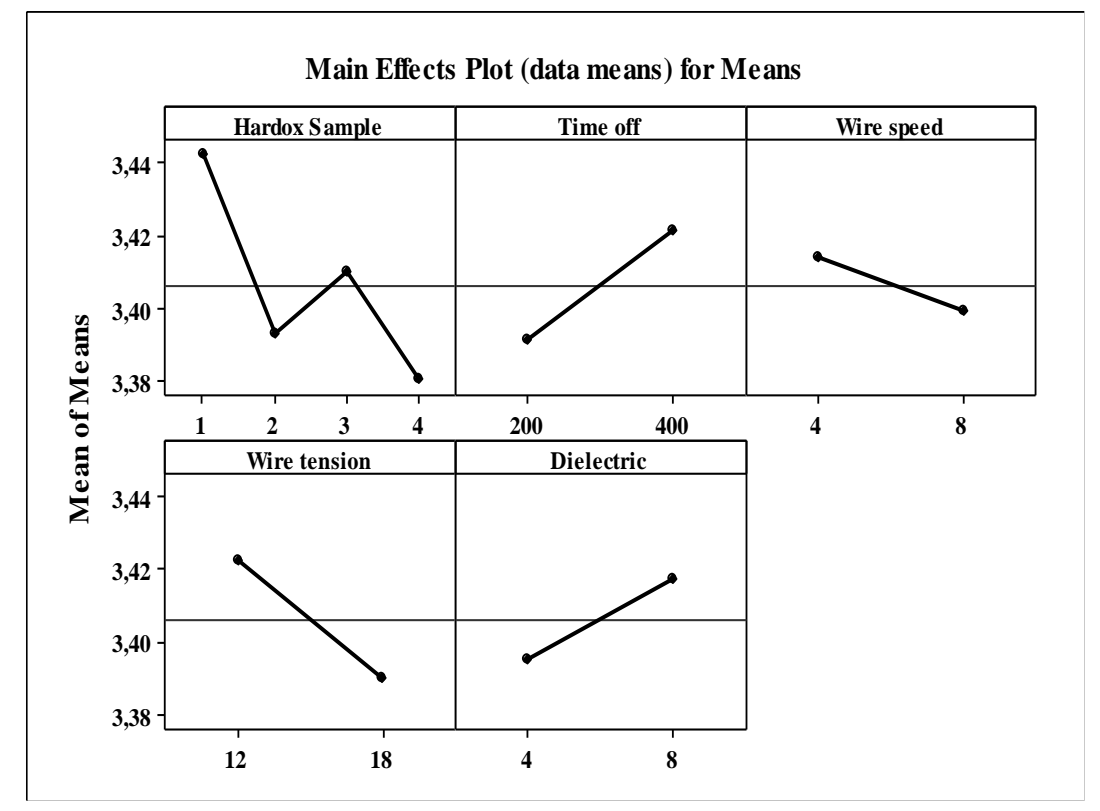

Figure 11. Effects of parameters on $\mathrm{Ra}(\mathrm{HAZ})$

In Table.8 ANOVA analysis with which the effects of welding method and WEDM parameters on kerf in the HAZ zone are examined. According to the Table, it was also observed that different welding method and WEDM parameters such as time off, wire feed and dielectric were significantly effective on kerf. The difference in kerf values of hardox samples welded by different welding methods and welding parameters shows the accuracy and contributions of the application. 
Table 8. Result of ANOVA for Ra of HAZ

\begin{tabular}{|lccccc|} 
Source & DF & SS & MS & F & P \\
\hline Hardox & 3 & 0,0088 & 0,0029 & 7,84 & 0,009 \\
\hline Time off & 1 & 0,0036 & 0,0036 & 9,60 & 0,015 \\
\hline Wire feed & 1 & 0,0009 & 0,0009 & 2,40 & 0,160 \\
\hline Wire Tension & 1 & 0,0042 & 0,0042 & 11,27 & 0,010 \\
\hline Dielectric & 1 & 0,0020 & 0,0020 & 5,40 & 0,049 \\
\hline Residual Error & 8 & 0,0030 & 0,0003 & & \\
\hline Total & 15 & 0,0225 & & & \\
\hline
\end{tabular}

\subsubsection{Welding metal}

$\mathrm{Ra}$ values of WM zone are given in Figure 10. According to the Figure the lowest Ra value was obtained with the samples 3, 4, 1 and 2. According to these results the lowest Ra value in the HAZ was obtained with the samples welded by the different MAG welding method. Again according to these results the lowest Ra values were obtained with the samples having the lowest conductivity. Besides, there is a general increase in the Ra values with the increase of time off and wire tension (WEDM parameters). However a general drop was observed in the Ra values with the increasing wire speed dielectric values. Similar results show analogy with some studies in literature $[5,11,23]$. The main reason of the discrepancies between Ra values of the samples in WM zone is the microstructure, micro hardness and conductivity values that change depending on the heat inputs of welding parameters.

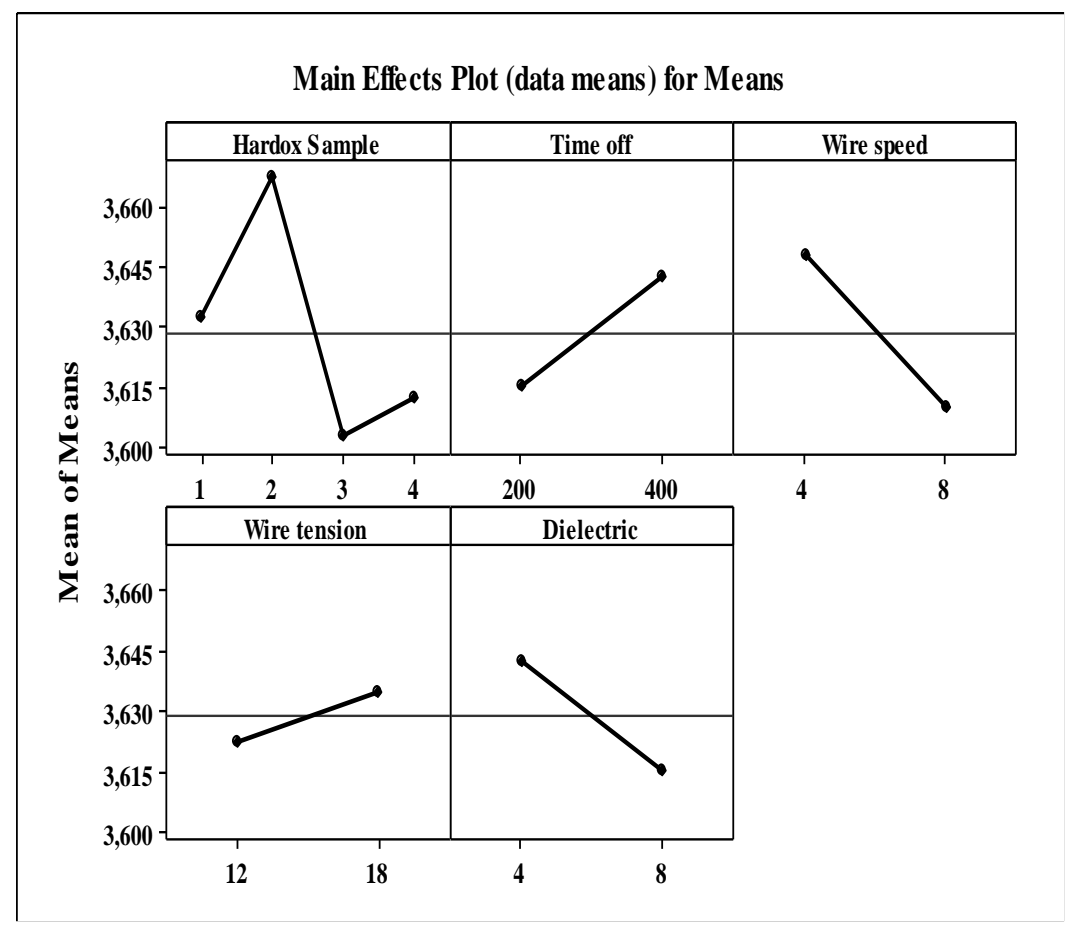

Figure 12. Effects of parameters on $\mathrm{Ra}(\mathrm{WM})$

In Table 9 ANOVA analysis with which the effects of welding method and and WEDM parameters on kerf in the WM zone is examined. According to the Table different welding method and WEDM parameters such as wire speed and dielectric were significantly effective on kerf. The difference in kerf values of hardox samples welded by different welding methods and welding parameters shows the accuracy and contributions of the application. 
Table 9. Result of ANOVA for Ra of WM

\begin{tabular}{|lccccc|} 
Source & D & SS & MS & F & P \\
\hline Hardox & 3 & 0,0098 & 0,003 & 7,31 & 0,01 \\
\hline Time off & 1 & 0,0030 & 0,003 & 6,72 & 0,03 \\
\hline Wire feed & 1 & 0,0056 & 0,005 & 12,5 & 0,00 \\
\hline Wire Tension & 1 & 0,0006 & 0,000 & 1,39 & 0,27 \\
\hline Dielectric & 1 & 0,0030 & 0,003 & 6,72 & 0,03 \\
\hline Residual Error & 8 & 0,0036 & 0,000 & & \\
\hline Total & 15 & & & & \\
\hline
\end{tabular}

\section{CONCLUSION}

Hardox 400 sheets were welded by a Plasma and Mag welding method. The mechanical and microstructure properties and machinability with the WEDM of these plates were examined. Different welding jointed were carried out to the samples of Hardox 400 used in the industry and their microstructure, microhardness and conductivity characteristics were changed. Effect of this characteristic change on machinability with WEDM was investigated with Taguchi method and ANOVA. These results was determined.The following conclusions were obtained:

- In both of the HAZ and WM zones the lowest hardness was observed with MAG welded sample 4 having $204 \mathrm{HV}, 200$ ampere and $0,15 \mathrm{~mm} / \mathrm{min}$ feed.

- In WM, conductivity of the sample 3 welded by MAG welding (having a low resistivity and higher conductivity) came out to be high. In HAZ, the value with the lowest resistivity and the highest conductivity was observed with the sample 2 welded by plasma welding.

- The lowest kerf value in the WM zone was measured with the sample 2 welded by plasma welding. Again in the WM zone, according to ANOVA results, the most effective parameters on kerf were found to be the welding method and WEDM parameter time off. The lowest kerf value in the HAZ was measured with the sample 1 welded by plasma welding. Besides, acoording to ANOVA results, the most effective parameters on kerf in the HAZ were found to be again welding method and WEDM parameter time off .

- The lowest Ra value in the WM zone was measured with MAG welded sample 3. Again according to the ANOVA results in the WM zone the most effective parameters on Ra were welding method and WEDM parameter wire feed. The lowest Ra value in the HAZ was measured with the MAG welded sample 4. Besides, according to ANOVA results the most effective parameters on Ra in the HAZ were again the welding method and WEDM parameter wire tension.

\section{ACKNOWLEDGEMENTS}

This study is supported by Inonu University Scientific Researches Projects (FBA-2018-610). We thank to the Rectorate of Inonu University for their support.

\section{REFERENCES}

[1] Tosun N, Cogun C, Tosun G. A study on kerf and materials removal rate in wire electrical discharge machining based on taguchi method. Journal of Materials Processing Technology 2004; 152: $316-322$.

[2] Gupta P, Khanna R, Gupta RD, Sharma N. Effect of process parameters on kerf width in WEDM for HSLA using response surface methodology, Journal of Engineering and Technology, 2012; 2:1-6.

[3] Yan MT, Huang PH. Accuracy Improvement of WireEDM by Real-Time Wire Tension Control. Int. J. Mach. Tools Manuf. 2004; 44: 807-814. 
Altuğ / Eskişehir Technical Univ. J. of Sci. and Tech. A-Appl. Sci. and Eng. 20 (1)-2019

[4] Hsue AWJ, Su HC. Removal Analysis of WEDM Tapering Process and Its Application to Generation of Precise Conjugate Surface. Journal of Materials Processing Technology 2004; 149:117-123.

[5] Aqueel S, Mufti NA, Rakwal D, Bamberg E. Material Removal Rate, Kerf, and Surface Roughness of Tungsten Carbide Machined with Wire Electrical Discharge Machining. Journal of Materials Engineering and Performance 2011; 20: 71-76.

[6] Jangra K. Jain A, Grover S. Optimization of multiple-machining characteristics in wire electrical discharge machining of punching die using grey relational analysis. Journal of Scientific and Industrial Research 2010; 69: 606-612.

[7] Rakwal D, Bamberg E. Slicing, Cleaning and Kerf Analysis of Germanium Wafers Machined by Wire Electrical Discharge Machining. Journal of materials processing technology 2009; 209: $3740-3751$.

[8] Mahapatra SS, Patnaik A. Optimization of wire electrical discharge machining (WEDM) process parameters using Taguchi method. International Journal of Advanced Manufacturing Technology 2007; 34: 911-925.

[9] Hari S, Khanna R. Parametric optimization of Cryogenic treated D-3 for cutting rate in wire electrical discharge machining, J Eng. Technology 2011; 1: 59-64.

[10] Kansal HK, Singh S, Kumar P. Parametric optimization of powder mixed electricaldischarge machining by response surface methodology. Journal of Materials ProcessingTechnology 2005; 169: 427-436.

[11] Altug M, Erdem M, Ozay C, Bozkır O. Surface roughness of Ti6Al4V after heat treatment evaluated by artificial neural networks. Material Testing 2016; 58: 189-199.

[12] Altug M, Erdem M, Ozay C. Experimental investigation of kerf of Ti6Al4V exposed to different heat treatment processes in WEDM and optimization of parameters using genetic algorithm. Int. J. Adv. Manuf. Technol. 2015; 78: 1573-1583.

[13] Frydman S, Konat L, Kalsk1 G. Structure and hardness changes in welded joints of Hardox steels, Archives Civil and Mechanical Engineering 2008; VIII: 15-27.

[14] Konovalov SV, et al. Formation Wear Resistant Coatings on Martensite Steel Hardox 450 by Welding Methods. Materials Science and Engineering 2016; 142: 2-5.

[15] Gökmeşe H, Özdemir M, The Effect Of Heat Treatment On The Formability Behavior Of Hardox-500 Sheet Material. Gazi University J. Sci Part:C 2016; 4: 343-349.

[16] Filip AC, et al. Experimental research on the machinability of Hardox steel by abrasive waterjet cutting. DOI: 10.1051/matecconf/20179403003 2017.

[17] Chamarthia S, et al. Investigation Analysis of Plasma arc cutting Parameters on the Unevenness surface of Hardox-400 material. Procedia Engineering 2013; 64: 854-861.

[18] Mindivan H. Effects of Combined Diffusion Treatments on the Wear Behaviour of Hardox 400 Steel. Procedia Engineering 2013; 68: 710-715. 
Altuğ / Eskişehir Technical Univ. J. of Sci. and Tech. A-Appl. Sci. and Eng. 20 (1)-2019

[19] Gondalia RV, Sharma AK. Parametric Investigation and Optimization of Co2 Laser Cutting process used for Cutting Hardox-400 materials. International Journal of Science and Engineering Applications 2013; 2: 123-129.

[20] Prajapati BD, Patel RJ, Khatri BC. Parametric Investigation of CO2 Laser Cutting of Mild Steel and Hardox-400 Material. International Journal of Emerging Technology and Advanced Engineering 2013; 3: 204-208.

[21] Majerik J, Barenyi I. Experimental Investigation Into Tool Wear Of Cemented Carbide Cutting Inserts When Machining Wear Resistant Steel Hardox 500. Engineering Review 2016; 36: 167174.

[22] Montgomery DC. Design and Analysis of Experiments, Wiley, New York, USA, 2001.

[23] Altuğ M, Gündüz ME, Aydemir E, Ballıkaya H, Özay Ç. Investigation of Surface Roughness of Welded Jointed Hardox Steel in WEDM, 9. International Congress on Machining; 8-10 November 2018; Antalya, Turkey. pp. 271-276. 